\title{
Reconciliation: A way of life for the world
}

\author{
M Masango \\ (University of Pretoria)
}

\section{ABSTRACT}

\section{Reconciliation: A way of life for the world}

This article deals with the issue of reconciliation as a new way of life for the world. It focuses on scriptural passages that support the topic. It also examines the spiritual aspect of reconciliation which is forgotten by many writers. It seeks to restore harmony in relationships, especially where there are broken relationships. It challenges people to seek the truth as South Africans did, through the Truth and Reconciliation Commission (TRC).

\section{INTRODUCTION}

The word reconciliation suggests that something has gone wrong within the system, hence the need for reconciliation. The word also assumes that there is conflict either between two people, notions of tension in relationships. Paul shares some insights about this word in the book of Corinthians:

"So if anyone is in Christ, there is a new creation, everything old has passed away, see, everything has become new (17). All this is from God, who reconciled us to himself through Christ, and has given us the ministry of reconciliation (18), in Christ God was reconciling the world to himself, not counting their trespasses against them, and entrusting the message of reconciliation to us (19). So we are ambassadors for Christ, since God is making his appeal through us, we entreat you on behalf of Christ, be reconciled to God (20)" (2 Cor. 5:17-20).

The word 'reconciliation' or 'reconcile' means a change from a state of enmity to one of friendship, or healing of a quarrel, or a radical change occurs in which an intimate and personal relationship is renewed or repaired. Martin suggests that "there was a real friendship, first existing, then broken, and finally restored” (Martin 1981:109). The reader can clearly see that reconciliation is our greatest challenge in the twenty first century, because we live in the world in which super 
powers are fixing their muscles against developing countries, in search of resources. We now live in a violent society. This world also shares a vision of hope, if we achieve reconciliation. Hope encourages hope for a peaceful future. If we do not work for justice and creation of peace, then the next generation will reap the fruits of conflict, violence and hatred. If we address the above, our children will embrace reconciliation that is life changing, transforming the world into a long lasting peace. Once again let me remind the reader that Paul uses the word a few times, especially when he talks about healing the divisions between Jews and Gentiles, male and female, slave and free. It this is achieved, an intimate and personal relationship is renewed, then we will be able to live in a peaceful atmosphere. Webster's' dictionary suggests the following when sharing about reconciliation: "restored to friendship or harmony, settle, resolve differences, or to cause to submit to or accept” (Woolf 1973:965).

When one analyses this word from the Greek "kattallasso", one finds a suggestion of a real friendship, first existing, then broken as the relationship continues, then brokenness comes in and affects the relationship, and when people work on their relationship, they finally restore it. When Paul uses the word "reconciliation", he applies it to a spiritual dimension, while Martin adds to this thought the announcement of reconciliation, which is expressed in personal terms. In the ministry of our Lord, we see Christ reconciling people into loving relationships, set up with the person's always in view (Martin 1981:130) - using this word suggests that there are pre-existing barriers to relationships. In short, reconciliation signals the reconnecting of those who have parted company. South African people know something about broken relationships, which separated them during apartheid years. They also managed to work through broken relationships, and began the journey of reconciliation - thus introducing a new way of relating to each other in the world.

It is interesting to note the Paul uses this word a few times in Scripture. For example in 2 Corinthians 5:18-19; Colossians 1:20, 22; Romans 5:10-11; Romans 11:15, and Ephesians 2:16. He seems to reserve this word for use as the most powerful way of expressing the meaning of life, death and resurrection of our Lord Jesus Christ. In other words, the coming of our Lord in the world offers people such a 
powerful new opportunity of reconciliation, with each other and with God. The following phrases, when combined together capture the true meaning of reconciliation:

a) being put into a relationship with God and with each other;

b) a radical change and transformation of a relationship;

c) finally, restoration harmony among people who clashed.

The main focus of humanity is to be reconciled to God and to each other. Through Jesus Christ all of humanity is reconciled to God, who so loved the world and gave God's only son, so that we may be reconciled to God. In other words, human beings are invited to respond to God's initiative in reaching out to us sinful creatures. Theology always highlights insights that are worth sharing when making peace with God, or atonement (at-one-ment). This is how Jews understood the concept of reconciliation with God. The Greeks on the other hand used the word reconciliation as a way of describing the results of individuals who had been in opposition to each other, and now becoming friends again. But they did not apply this concept to God (Martin 1977:196). When Paul wrote about the concept of being reconciled to God, to the Greeks, it was embracing a new concept. In other words, one would say that reconciliation with and through Jesus Christ was often "a stumbling block to Jews and foolishness to Gentiles” (1 Cor 1:23). According to the Jewish concept the process of reconciliation begins when an individual accepts God's invitation to make things right. Every human being according to Paul is in need of this peace with God. Once we recognise that we are estranged with God, through our Lord Jesus Christ we can be reconciled to the one who created us. Paul captures this whole truth in the book of Colossians:

"And you who were once estranged and hostile in mind, doing evil deeds (21), he has now reconciled in his fleshly body through blameless and irreproachable before him (22) - provided that you continue securely, established and steadfast in the faith, without shifting from the hope promised by the gospel that you heard, which has been proclaimed to every creature under heaven, I, Paul became a servant of this gospel (23)" (Col 1:21-23).

It is because of sin that our relationship with God became fractured. Death on the cross was understood as the action that repaired our 
relationship with God. In other words, to be reconciled to God, then is to move from estrangement to friendship. This is what happened to Paul on the Damascus road - a radical change, which set him loose to relate to those he had hated before. All animosity and bitterness were removed by that experience, and being reconciled to God, he was able to recognise the image of God in other people. Reconciliation is therefore a divine gift from God, which was costly. It brings peace to those who experience it, and it introduces one into life in its fullness. This experience was shared by some of the violators after sharing their painful way of torturing and killing blacks. My own analysis is that reconciliation is a process of healing that heads to freedom and liberation. In Paul's words: "if any person is in Christ, that person is a new creature, the old things have passed away, behold all things have become new" (2 Cor 5:17).

When Paul was reconciled to God, he became a new creature, the old torturing of Christians was passed, and he cared for people he once hated. Paul underwent a radical change, which reconciled him to God and fellow human beings. Once a person experiences the above change, he/she will never be the same. In other words, change takes over and introduces the new order in the life to those who were in conflict. One can understand why South Africa underwent such a radical change, i.e. from dysfunctional to normal. This process came as the result of churches having sought the truth instead of punishment. The reader should remember that "the truth shall set you free". De Young reminds us that when people change certain elements occur. He says: "Through a process of casting off the dysfunction in our emotions, spirit, psyche, and relationships, a person becomes healthy” (De Young 1997:46).

This process begins with God, and then it strengthen a person to live as a new creature with other creatures, even though (in certain circumstances) our environment and world often do not change.

In this ministry of reconciliation one seeks to follow the truth. You are forced to minister to perpetrators of crimes, enabling them to become clean and helping them to become morally responsible citizens. On the other hand, you have to help survivors (victims) to tell their own stories, and in doing so, you help them deal with their own hurts, anger and their wounds which affected them during the time of their violation. The reader will now understand why South Africans chose 
the way of reconciliation through the Truth and Reconciliation Commission (TRC). As leaders of the churches we had to struggle with the issue of reconciliation and forgiveness. The TRC commission helped South Africans to pursue the truth, by focusing on stories of the lives of their beloved who had disappeared. These stories would have disappeared from our history, and families would have not known the truth. In other words. Of the South African Council of Churches General Secretary, when reflecting on the TRC said:

"The commission for Truth and Reconciliation is not another Nuremberg Trial. It turns its back on any desire for revenge. It represents an extraordinary act of generosity by a people who only insist that the truth, the whole truth and nothing but the truth be told. The space is thereby created where the deeper process of forgiveness, confession, repentance, reparation and reconciliation can take place” (Baum \& Wells 1997:28).

The above statement challenged South Africans, as well as the whole world. It is also calling us to the ministry of reconciliation and healing of people and nations that are experiencing conflict. Finally, it challenges the world to get involved in the ministry of reconciliation. It invites us to be ambassadors of reconciliation. This process needs people who are committed to rebuilding lives where there is conflict and violence. Let us now analyse the process of ambassadorship.

\section{AMBASSADORS OF PEACE}

The above experience of change in the life of Paul moved him to another challenge - that of being an ambassador for Christ. Once you are reconciled with God (the divine) - you have to deal with humanity (neighbour). Continuing in his journey of change, Paul became an ambassador of Christ in the area of preaching the word, reconciling people and healing relationships. He was now acting on behalf of God, removing barriers that destroyed relationships among Jews and Gentiles. Today the world is struggling with all kinds of racism, sexism, classism and many kinds of sexisms. Ambassadors are first call to deal with their sexisms before they can have a word with other people. The writer has struggled with the issue of hatred, prejudice, jealousy and suspicion. I continue to struggle with the above, as I relate to others. When I know what is happening, it helps the process. Once a 
person is aware, it helps one to deal with the problems. I also have to continue to strive for peace, justice, equality and integrity.

As a Christian it is an honour and a privilege to be God's ambassador of reconciliation. In fact, to be a Christian by definition is to be installed in the ministry of reconciliation, we are called to the ministry of healing broken relationships between people, nations and other religions. De Young reminds us of the power of reconciliation by saying that "reconciliation is accomplished when we live it out in relation to each other" (De Young 1997:69).

The main aim of reconciliation is to bring people together in such a way that they may begin to deal with their conflict in the midst of their tension. As ambassadors we are called to be mediators, creating space where all the struggles against injustice can be challenged. The process will allow the Holy Spirit to take over. South Africans have for decades lived in this tension, and TRC provided a space, which allowed the perpetrators to meet the people they violated (survivors). Baum is reminding us of grace as people work for reconciliation. He says:

"we discovered and experience God's forgiveness of our trespasses and this prompts us to repentance. In the reconciliation process, then, because the victim has been brought by God's reconciling grace to forgive the tormentor, the tormentor is prompted to repent of evildoing and engage in rebuilding his or her humanity" (Schreiter 1992:45).

Of course this does not always happen, and it is rarely a swift or simple process. Sometimes peaceful co-existence is all that can be achieved. Authentic reconciliation may take a very long life. As Schreiter insists, it is "not a managed process" (Schreiter 1992:45). People cannot be merely exhorted or manipulated into truly heart-felt reconciliation. It most often has to be initiated from the side of the victim, since the perpetrators are often unable to forgive themselves or even to recognise with honesty the enormity of what they have done. Schreiter says: "it comes upon us like a healing, for reconciliation is something that comes upon the victim, something that the victim discovers, rather than a well-managed therapy or process. It is more a spirituality than a strategy" (Schreiter 1992:70-71). 
The reader can understand why South Africans intentionally had worship services before the hearings. Worship prepared victims, perpetrators and the whole community to receive the painful stories. In short, this journey of hearing the stories moved us to repentance, forgiveness and reconciliation - which are part of the ongoing mission of Christ Jesus, guided by the power of the Holy Spirit. The reader will also realise that reconciliation is relational, first with God, then with each other. It is accomplished when we live it out in relation to each other. The above process can only happen when people relate to each other as equals, not as superior and others as being inferior. Reconciliation sets people free, if it does not free people, then it is not the kind practised by Jesus, and proclaimed by Paul. Tutu actually says that "True reconciliation occurs when one confronts people with the demands of the gospel of Jesus for justice and peace, and compassion and caring" (Tutu 1990:41).

The above quote simply means that one takes sides on behalf of the weak and the down trodden, the voiceless ones. It is important to note that we cannot be neutral in situations of injustice, oppression and exploitation. It short, reconciliation is not just getting along with each other. It means working at the conflict that has divided you, keeping the tension until you are able to confront the truth. It is a radical transformation in the way we relate to each other within a divided society. Our efforts at weaving relationships together need to be interwoven with opportunities for setting people free. This process was central to the ministry of our Lord. Throughout the Scriptures we find Jesus Christ pursuing liberation and reconciliation amid the powerless, the poor and the marginalized. He finally confronted and dismantled oppressive systems of injustice that humiliate the downtrodden (oppressed). De Young reminds us that reconciliation requires that we are led to reconcile with the other person (De Young 1992:76). South Africans were able to confront the injustices with the truth, by creating a system of healing which leads to reconciliation between Black and White, as well as perpetrator and victims. Through the TRC, South Africans were able to deal with their hurts, injustices and differences. People became free after sharing their problems of how they participated in torturing others in prison. De Young had this to say about reconciliation: 
"Reconciliation requires that people be committed to setting others free, spiritually, emotionally, psychologically, socially and physically” (De Young 1997:77).

Roberts shares another interesting concept worthy to be noted among the oppressed people. He says "reconciliation and liberation are intertwined because Christ is at once the liberator and reconciler" (Roberts 1994:ix). Looking back at the South African experience of apartheid, for reconciled relationships to have been sustained, we needed a process of cleansing, which held people on equal basis in order to achieve freedom. TRC, with powers given by the government, made it possible for all voices to be included, valued, and encouraged to share all. One way of nurturing reconciliation is to be able to hear the stories of people who have been hurt, violated and oppressed. Sharing their stories as perpetrators relate them publicly. This process set people on a journey of healing, which opened a space for reconciliation. In this process the voiceless were invited to conversation with perpetrators, so as to engage them in their injustices, and their misuse of power. Maguire shares some of the struggles of Northern Ireland stories of injustice. He says:

"Men and women must truly seek to hear each other's stories. We need to learn to hear the voices of all our brothers and sisters in the human family. To accomplish this, those who have power in society (or the church), and they already have a voice, will need to listen more" (Maguire 1994:18).

Hearing the stories and dialogue that are part of the healing process that leads to reconciliation. In other words, hearing and receiving stories of the marginalized, open a way to dialogue. This can only happen when our life intersect and interconnect with the lives of others. People have to learn to leave their comfort zones, and relate to people whose lives differ from their own. In oppressive South Africa, Whites had to step out into the unknown, while Blacks had to learn to join hands with the oppressor together. They will be led to the unknown ground or space, and then both discover each other as they struggle to relate. Though this process then the views of those who struggle together will be radically altered, especially when people have their places of comfort, and they then experience a fresh perspective. Finally, it is important to gain 
some ability to see life through the eyes of others, especially the oppressed.

The process of reconciliation embarked on by South Africans included all voices and viewpoints. It was more than just listening to traditionally unheard (or oppressed) voices. It included the powerless and powerful, business groups, church leaders, and educational institutions. The main aim was to heal the land and the people irrespective of colour or creed. It was also done in public where stories could be heard by the people and the rest of the world. The reader needs to know that the process was not perfect - it had its down side. The purpose of this article is to focus on reconciliation and not on the TRC's falls. I need to warn the reader that no one can fully understand the pain of the victim. We can never fully know what it is like to be another person. When groups or individuals who have been victimised begin to move towards reconciliation, they may experience rage, fear, loneliness and many other forces of anger. As care givers, we must allow them to work through this journey. It is important to note that people who have experienced injustice should always question whether they could possibly be victimised or marginalized again. Trust becomes a real issue at this point in their journey. The oppressor must also deal with the issue of misuse of power. They must be willing to let go of power or to acknowledge wrong doings, which has an element of risk in trusting the process of reconciliation. Pannell reminds us of an important part of relationship building which leads to trusting each other. He says:

“The willingness to receive a person's rage rather than run away or be defensive helps build trust. Daring to trust requires the ability to listen to the truth spoken by angry pain-filled voices" (Pannell 1993:89).

As people continue to work on the issue of trust in the midst of tension, they come closer towards reconciliation. In the journey of conflict there comes a time when issues need to be addressed, before they can move on to deeper issues of tension, and grow in the ability to trust, and also to be trusted. This process requires great courage. The next step in this process will be repentance and forgiveness, which is the gift from God, introduced to human beings through Jesus Christ. Forgiveness is a healing act, which releases the pain that comes from anger or fear. It 
finally opens the door for reconciliation. When the other person responds, it leads the two to come together in a new relationship. The reader needs to note that, without forgiveness there is no reconciliation. This process is emphasised by Bishop Tutu, connecting it to the African spirit of "ubuntu” (human dignity or humanity). He says:

"The spirit of ubuntu's its central concern is on the healing of bridges, the redressing of imbalances, the restoration of broken relationships, seeking to rehabilitate both the victim and the perpetrators, who should be given the opportunity to be reintegrated into the community he/she has injured by his/her offence" (Tutu 1999:35).

The above approach seeks to lead the ruptured relationships into healing. In short, one would claim that justice, restorative justice, is being served when efforts are being made to work for healing, for forgiveness, and for reconciliation. The act of forgiving in the process becomes a freeing experience. Many of the perpetrators were relieved, one them actually said these words after confessing his story to the TRC:

"I am glad to have shared this story. For years I could not sleep. Tonight I will be able to sleep” (Tutu 1999:45).

It is important that people should not focus on cheap ways of forgiveness. Forgiveness that leads to reconciliation is costly. This process allows you to confront your sinful nature, it then opens anger, and rage from the victim. Therefore people should focus on anger and injustice rather than on social structures that operated during the violation. In other words, people should not only focus their attention on the preparation. If we do, then revenge has raised its ugly head; it will simply increase the separation between those who are willing to work on reconciliation. The next step is confession and repentance, which are part of the process of forgiveness that leads to reconciliation. This process cannot be skipped or neglected. God through Holy Scriptures reminds us about revenge, vengeance is mine, and recompense, for the time when their foot shall slip because the day of their calamity is at hand, their doom comes swiftly (Dt 32:35). 
Romans also emphasize this idea. Beloved never avenge yourself, but leave room for the wrath of God, for it is written vengeance is mine, I will repay, says the Lord ( $\mathrm{Rm} \mathrm{12:19).}$

As people continue with the struggle of forgiving each other, they will be able to recognise the humanity (bunt) in each other. Then their journey of forgiveness will lead them to liberation - the end product of reconciliation. De Young suggests that:

"Forgiveness grants us freedom (liberation) from our own personal history, or one we have inherited through society. It is often our mobility to let go of pain from the past that inhibits our ability to engage in efforts leading towards reconciliation in the present" (De Young 1997:101).

It is not easy for some one who has lived in oppressive regimes to connect with the above quotation, but when structures are place in such a way that his/her voice is heard, it allows one to join in on this journey of forgiveness. The reader needs to know that reconciliation is a long process, even after forgiving each other, people still struggle with the issue, it is similar to the pain of losing a loved one through death. It is not a once off journey, one needs to keep coming back to the pain, until you get healed. It is also important to note that deliverance from the prison of our past hurts or wrongs can be found through offering or receiving forgiveness. The tension of anger and forgiveness must be kept in a relationship, so that the victim and perpetrator continues to wrestle with these issues. There is also a time when the victim will not trust, this blocks the process of forgiveness. At this time, the process needs to give the victim space so that he/she works through this pain alone. This part of repairing the wrong done to the victim, will lead to restoration of trust. In short, actions of reaching out and repenting from the wrong when caused to others allow the other to enter into dialogue, which, if done properly, will lead to reconciliation.

\section{CONCLUSION}

It is important to remember that our faith is expressed through the living God who sent his only begotten son so as to forgive and reconcile human beings to God Almighty. All this occurred because of sin, which separated us from the glory of God. In short, our faith is expressed through reconciliation with God, our neighbours and 
ourselves. This is the centre of God's mission towards human beings. Because of his great love we need to respond by loving each other. As creatures or artisans that need to continue this work of the art given to us by the creator God, we are therefore called to the ministry of forgiveness and reconciliation, bridging relationships especially where there is conflict. De Young concludes that:

"we should be faith full in developing on God given reconsolidating gift when the context of separation and alienation divides people" (1997:112).

In other words, we should walk in grace with our enemies in such a way that we develop relationships that lead to healing. The world we live in needs artisans who can properly focus on their ability of helping people take responsibility, encouraging forgiveness, repairing wrongs, healing souls, and creating new ways of relating in the mist of conflict. Bonhoefer is a great example. During difficult times in Germany he decided to come back from the U.S. in order to share the problems by his fellow citizens during Hitler's times. Bonhoeffer wrote to Reinhold Neibuhr a letter explaining why he must return.

"I have made a mistake in coming to America (he said) I must live through this difficult period of our national history with the Christian people of Germany. I will have no right to participate in the reconstruction of Christian life in Germany after the war if I do not share the trials of this time with my people, I would have failed them and my God (Edwin 988:170).

This is a typical way of commitment to freedom and reconciliation, even unto death; not cheap reconciliation but a very costly kind. Bonhoeffer continues by saying

"when Christ calls a man (sic) he bids him come and die" (1988 172).

Those who work for reconciliation confront the misuse of power with the truth of God. The reader will now realise that people who stand for the truth and love, are killed, just like their master, our Lord Jesus Christ - but their truth remains challenging those who killed them. One cannot forget the words of Martin Luther King jr. (USA), Bonhoeffer (Germany), Ghandi (South Africa/India) and many other heroes. Let us 
continue the good works of those men and women and of the rest of South Africans.

\section{Consulted literature}

Baum G and Wells H 1997. Reconciliation, challenges to the Churches. New York: Orbis books: Maryknoll.

De Young C P 1997. Reconciliation our greatest challenge, our only hope. Judson press valley forge, Pennsylvania.

-, 1998. Reconciliation hop[e for the world, Judson Press Valley Forge, Pennsylvania.

-, 1995. Coming together: The Bible message in an age of diversity. Judson Press Valley, Pennsylvania.

Former H H 1998. Reconciliation and religion, some aspect of uniqueness of Christianity as a reconciling faith. Cambridge: Edwin Mellen Press.

Ditmanson H H 1977. Grace in experience and theology. Minneapolis: Augsburg Press.

Maguire M 1994. Reconciliation: Having the courage to heal. The Netherlands: Alkmare Press.

Martin R P 1981. Reconciliation: A study of Paul's theology. Atlanta: John Knox Press.

Pannel W 1993. The coming race wars? A cry for reconciliation. Zondervan, Michigan: Grand Rapids.

Roberts D J 1994. Liberation and reconciliation - A black theology. New York: Orbis books, Maryknoll.

Schreiter R J 1992. Reconciliation: Mission and ministry in a changing social order. New York: Orbis books, Maryknoll.

Tutu D M 1999. No future without forgiveness. New York: Double day Publishers, Random house.

Woolf H B 1973. Webster's New Collegiate Dictionary. Michigan: G and C Merriam Company, Spring field.

\section{Magazine:}

Wells S D 1990. Woven together in love, a journey of the Christian spiritual life Vol. V number 1 January/February. 